\title{
Em defesa da república: Sidney, leitor de Maquiavel
}

\author{
In defense of the republic: Sidney, reader of Machiavelli
}

\begin{abstract}
Alberto Ribeiro G. de Barros*
Resumo: John Pocock consagrou a tese de que o republicanismo inglês foi uma simples manifestação do republicanismo de Maquiavel. De fato, muitos autores ingleses do século XVII recorreram aos Discursos sobre a primeira década de Tito Lívio para defender a República estabelecida na Inglaterra entre I649 e I660. Mas nem sempre essas defesas reproduziram fielmente seus enunciados, abandonando muitas vezes seus princípios e suas consequências. O objetivo deste artigo é mostrar que a apropriação do republicanismo de Maquiavel menos problemática neste período foi feita por Algernon Sidney em seus escritos políticos.
\end{abstract}

Palavras chave: Sidney, Maquiavel, República, republicanismo

\begin{abstract}
John Pocock established the thesis that the English republicanism was a simple manifestation of Machiavelli's republicanism. In fact, many English writers of the seventeenth century employed the Discourses on Livy to defend the Commonwealth established in England between I649 and I660. However, not always these defenses reproduced truthfully their statements, abandoning their principles and their consequences. This article intends to show the adoption of Machiavelli's republicanism less problematic in this period was made by Algernon Sidney in his political writings.
\end{abstract}

Keywords: Sidney. Machiavelli, Commonwealth, republicanism

\footnotetext{
" Professor Associado de Ética e Filosofia Política do Departamento de Filosofia da USP e Pesquisador do $\mathrm{CNPq}$. Este artigo integra projeto de pesquisa financiado pelo CNPq.
} 
Felix Raab, em The English Face of Machiavelli: a changing interpretation I500-I700, descreve com detalhes a propagação da obra de Maquiavel na Inglaterra, desde suas primeiras traduções até sua plena incorporação no debate político inglês, que teria sido marcada pela multiplicidade de interpretações e pela sua mútua apropriação por parte de adversários políticos ${ }^{\mathrm{I}}$.

No decorrer das guerras civis (I642-I648), por exemplo, O Príncipe teria sido utilizado tanto pelos realistas, para defender a necessidade do poder absoluto de Carlos I e a obrigação incondicional de obediência dos súditos, quanto pelos parlamentaristas, para denunciar o exercício tirânico do poder real e fundamentar a rebelião. Depois da execução do rei, em janeiro de I649, a imagem do príncipe maquiaveliano teria sido empregada tanto pelos realistas, para criticar a falsidade e hipocrisia dos generais do exército parlamentar, quanto pelos parlamentaristas, para justificar as ações do novo governo, com base no argumento de que muitas vezes as circunstâncias exigiam a dissimulação, a fraude e o uso indiscriminado da força (Raab, I965, pp. IO2-I29; pp.I36-I44).

Com o início da República, instaurada em maio de I649, alguns publicistas ingleses teriam deslocado sua atenção para os Discursos sobre a primeira década de Tito Lívio. Se o nome de Maquiavel ainda era associado ao exercício tirânico do poder, sustentado em práticas imorais e iníquas, ele também passou a ser evocado como o principal porta-voz moderno dos valores republicanos (Raab, 1965, pp. I68-I94).

De fato, no período de vigência da República (I649-I660), esta obra foi abundantemente citada e utilizada pelos defensores do novo regime. Talvez por isso John Pocock, em The machiavellian moment: florentine political thought and the atlantic republican tradition, defenda que o republicanismo inglês foi uma manifestação do humanismo cívico de Maquiavel, cuja maior expressão estaria na obra de James Harrington, Commonwealth of Oceana, publicada em I656. É bom lembrar que Pocock considera o humanismo cívico um discurso político herdado do aristotelismo, fundado numa linguagem da virtude, da participação ativa dos cidadãos na vida pública e da devoção ao bem comum, que teria sido transmitido da Florença renascentista para a Inglaterra seiscentista, de onde teria migrado para as colônias americanas, vindo a influenciar decisivamente a luta pela independência e a formação da República norte-americana (Pocock, 1975, pp. 383-400).

\footnotetext{
I Foram traduzidos para a língua inglesa em I52I, Arte da Guerra; em I53I, O Príncipe e Discursos sobre a primeira década de Tito Lívio; em 1532, História de Florença. Pelo menos desde o panfleto de Richard Morison, A Remedy for Sedition (1536), há referências explícitas às ideias de Maquiavel no debate político inglês. Embora os seus escritos tenham sido proibidos no reinado de Elisabete I (I558-I603), eles continuaram a circular em manuscritos, no início da dinastia Stuart. Entre i636 e I640, Edward Dacres publicou novas traduções, popularizando o pensamento político de Maquiavel.
} 
No entanto, é preciso reconhecer que esta manifestação foi apenas parcial, no sentido de que os fundamentos do pensamento republicano de Maquiavel não foram completamente acolhidos pelos defensores da República. Ao adaptá-lo à tradição política e constitucional da Inglaterra, os republicanos ingleses acabaram modificando os seus mais importantes pressupostos e abandonaram o que havia nele de mais original (Barros, 20I5, pp. 302-333; pp. 434-439).

Além disso, a mais clara enunciação desse republicanismo mitigado de Maquiavel não se encontra na obra de Harrington, mas nos escritos políticos de Marchamont Nedham (Barros, 20I4, pp. 22-39). Responsável pelo semanário oficial da República, Mercurius Politicus, Nedham recorreu com frequência aos Discursos sobre a primeira década de Tito Livio para defender o novo governo. Em seus editoriais, reunidos posteriormente em um tratado intitulado The Excellencie of a Free State, publicado em 1656, ele reproduziu vários argumentos utilizados por Maquiavel em favor do regime republicano, mas também sem acolher os fundamentos sobre os quais eles estavam construídos ${ }^{2}$.

Com o fracasso da experiência republicana e a restauração da monarquia, poucos publicistas ingleses ousaram recorrer ao republicanismo de Maquiavel, seja para atacar o novo monarca, seja para propor o retorno da República. Algernon Sidney foi um dos raros autores a fazê-lo. Descendente de duas ilustres famílias aristocráticas, ele encontrava-se na Irlanda, onde seu pai comandava as tropas do rei, quando teve início a guerra civil. Logo depois de retornar à Inglaterra, passou a apoiar a causa do Parlamento, tornando-se coronel de um dos regimentos do exército parlamentar. Após um período de convalescença, em razão de ferimentos sofridos no campo de batalha, assumiu uma cadeira na Casa dos Comuns, em I646, e manteve-se depois do expurgo de seus membros mais conservadores, em I648, naquele que ficou conhecido como Parlamento Rump. Com o fim da guerra civil, recusou-se a participar da corte criada para julgar Carlos I, questionando a legalidade do procedimento judicial. Não deixou, porém, de participar do primeiro Conselho de Estado, órgão executivo do novo regime. Com a dissolução do Parlamento Rump, em 1653, retirou-se da vida política, sem deixar de criticar veementemente o Protetorado de Cromwell. Retornou à Casa dos Comuns, com o restabelecimento do Parlamento Rump, em I659, e foi novamente eleito para o Conselho de Estado (Ver Caswell, I989).

Como Maquiavel, enquanto fez parte do governo republicano, Sidney engajou-se nas questões envolvendo o exército e as relações internacionais. No primeiro Conselho de

\footnotetext{
${ }^{2}$ Nedham, The Excellencie of a Free State I, pp. 32-50; II, pp. I3I-I33.
} 
Estado, participou dos comitês para assuntos militares e estrangeiros, destacando-se em três frentes: a colonização da Irlanda; a guerra entre Inglaterra e Holanda; e as negociações para a incorporação da Escócia à Inglaterra. No último Conselho de Estado do regime republicano, encontrava-se numa missão diplomática na Escandinávia, para mediar o conflito entre Dinamarca e Suécia, quando a monarquia foi restaurada em I66o (Haydon, I96I, pp.IIO-I33).

Ao perceber a extensão da perseguição aos republicanos, com o retorno dos Stuart ao trono inglês, Sidney optou por um exílio voluntário, vivendo em diversos países: Alemanha, Itália, Suíça, França, entre outros. Também como Maquiavel, ele tornou-se um escritor político depois que o regime republicano, ao qual serviu com entusiasmo, entrou em colapso. No período em que residiu em Rotterdam, redigiu Court Maxims, enquanto negociava o apoio dos holandeses e ingleses exilados para a destituição de Carlos II e a restabelecimento da República³.

A obra descreve um longo diálogo, dividido em quatorze encontros, entre um bemintencionado cortesão, Philalethes, e um republicano, Eunomius, no qual são discutidas máximas da corte inglesa, supostamente inspiradas em $O$ Príncipe de Maquiavel. $\mathrm{O}$ primeiro encontro expõe a questão que dá origem à discussão. Philalethes pergunta por que o povo inglês, que desejou de maneira tão veemente o retorno da monarquia, parecia extremamente descontente com o governo de Carlos II. Eunomius responde que um povo não é feliz apenas por alcançar o que deseja, mas só se o seu desejo for realmente bom. Enganado pela fraude dos cortesãos e pela malícia do episcopado anglicano, o povo havia restaurado a servidão com o regime monárquico, rejeitando a liberdade que havia sido conquistada com tanto esforço ${ }^{4}$. É proposto então a análise das máximas que estariam orientando as ações do rei ${ }^{5}$.

Ao discutir a máxima que defende a necessidade de um monarca absoluto para a manutenção da ordem pública, Eunomius reconhece a importância de um prudente legislador no trabalho de harmonização dos diferentes humores e interesses do corpo político. Em seguida, defende que a tarefa deste grande homem, versado e exercitado na arte política, é realmente estabelecer e manter a ordem pública, para que os homens possam alcançar a felicidade. Mas como não há felicidade sem liberdade, e nenhum

\footnotetext{
${ }^{3} \mathrm{O}$ manuscrito de mais de 200 páginas foi descoberto no final do século passado pelo historiador Blair Worden, no Castelo de Warwick, e publicado pela primeira vez em 1996.

${ }^{4}$ Não se pode deixar de lembrar a reflexão de Maquiavel sobre a dificuldade do povo em reconhecer o verdadeiro bem, que é sua liberdade, e como o povo deseja muitas vezes sua própria ruína, enganado por uma falsa aparência de bem. Maquiavel, Discursos sobre a primeira década de Tito Lívio I, 53, pp.I52-I56.

${ }^{5}$ Sidney, Court Maxims, pp. 2-4.
} 
homem é mais escravo do que aquele submetido às suas paixões, sustenta que não há liberdade sem virtude. Assim, avalia que a política não é a arte da malícia, crueldade, astúcia e engodo, praticada na corte com base nos ensinamentos perniciosos de Maquiavel, mas a arte de governar conforme a justiça, para que a virtude possa se expressar e, consequentemente, a liberdade possa se efetivar ${ }^{6}$.

Maquiavel é citado ainda outras vezes como principal mentor das máximas da corte, seja por seus conselhos ao príncipe para renunciar à honra, justiça, verdade, caridade, religião e humanidade, se quiser manter o poder conquistado ${ }^{7}$, seja por sua defesa do uso da força e da fraude no exercício do poder ${ }^{8}$. Além de uma breve citação de História de Florença $a^{9}$, outra referência sem reprovação é feita apenas na discussão da máxima segundo a qual a corrupção dos juristas é útil à monarquia. Depois de criticá-la, com o argumento de que as sociedades civis foram criadas para instaurar a justiça, que é estabelecida pelas leis civis em conformidade com as leis divinas e com a reta razão, Eunomius adverte que ele não reprova os juristas nem o estudo das leis, mas apenas aqueles juristas mercenários da corte inglesa que sustentavam a tirania do rei. Ao retomar então a distinção aristotélica entre o rei e o tirano, defende o combate à tirania, mesmo com a força das armas, e lembra a advertência de Maquiavel de que, se as guerras civis acarretam enfermidades ao corpo político, a tirania resulta em sua morte ${ }^{\mathrm{IO}}$.

Se $O$ Príncipe é considerado a principal fonte de inspiração das máximas da corte, curiosamente Discursos sobre a primeira década de Tito Lívio permanece como a mais importante referência na sua refutação. Por exemplo, sobre a suposta superioridade das monarquias no campo militar, Eunomius sustenta que a história mostrava que, se fosse avaliado apenas o número de vitórias e a extensão das conquistas, a vantagem seria mesmo das monarquias, por causa de seu maior número. Mas se fosse examinado as dificuldades e outras circunstâncias das conquistas, a vantagem seria das repúblicas, por três principais motivos: as suas conquistas tiveram sempre como causa a própria virtude; as nações conquistadas pelas repúblicas eram mais valorosas do que aquelas conquistadas pelas monarquias; a história não registrava sequer uma república poderosa que havia sido conquistada por um monarca. Além disso, argumenta que a avaliação de um regime depende da finalidade para a qual ele se propõe. Se o seu objetivo for a conquista para a manutenção da liberdade, como em Roma, então a expansão dos domínios demonstraria

\footnotetext{
${ }^{6}$ Sidney, Court Maxims, p. 24.

${ }^{7}$ Sidney, Court Maxims, p. 84.

${ }^{8}$ Sidney, Court Maxims, p. 92.

${ }^{9}$ Sidney, Court Maxims, p. 73.

${ }^{\text {Io }}$ Sidney, Court Maxims, p. I47
} 
seu valor, mas se for a defesa para a proteção da liberdade, como em Esparta, a conquista não poderia servir de critério de avaliação ${ }^{\mathrm{II}}$.

O republicanismo de Maquiavel está também presente na demonstração da superioridade das repúblicas sobre as monarquias no que se refere às decisões dos assuntos públicos. Com base em vários exemplos históricos, Eunomius defende que as repúblicas sempre foram tão ou mais rápidas do que as monarquias na tomada e execução de importantes resoluções. As repúblicas são também mais constantes em suas decisões, uma vez que elas não dependem das inclinações e humores de um monarca, mas de leis e princípios que as regem; e se as suas assembleias podem ser afetadas pelas paixões de seus membros, elas estão menos sujeitas às inconstâncias do que o espírito de um só homem ${ }^{12}$.

Assim, Sidney mantém o antagonismo característico de sua época em relação ao pensamento político de Maquiavel. De um lado, O Príncipe é lido como um conjunto de conselhos nefastos, contrários à religião e à moral cristã, para um monarca conquistar e manter seu poder. Do outro, Discursos sobre a primeira década de Tito Lívio é visto como a mais veemente defesa do regime republicano, em que Roma é apresentada como modelo para as repúblicas modernas que desejam manter sua liberdade, entendida como independência em relação às potências estrangeiras e autonomia na elaboração e execução de suas próprias leis. Não é vislumbrada qualquer vinculação entre as duas obras, como se fossem duas perspectivas antagônicas de um mesmo autor.

Em 1673, Sidney obteve permissão para visitar a Inglaterra, mas preferiu permanecer no continente. Ele já havia escapado de algumas tentativas de assassinato e temia por sua vida. Só retornou em I677, quando recebeu uma nova permissão, para visitar sua família e tratar de assuntos pessoais. Com a morte do pai, permaneceu mais tempo do que esperava, envolvendo-se com litígios familiares por questões de herança. Candidatouse, sem sucesso, aos Parlamentos de I679 e I680, conseguindo eleger-se apenas no Parlamento de I68I, que ficou reunido menos de um mês.

Em junho de I683, Sidney foi um dos acusados de participar de uma conspiração malsucedida para assassinar o rei, Carlos II, e o duque de York, Jaime Stuart, o primeiro na linha de sucessão ao trono. Os manuscritos encontrados em sua casa, no momento de sua prisão, foram confiscados e algumas partes, em especial as últimas seções, que defendiam o direito de resistência e de revolta do povo contra um governo tirânico, foram utilizadas em

\footnotetext{
II Sidney, Court Maxims, pp. I5-I8. Ver Maquiavel, Discursos sobre a primeira década de Tito Lívio I, 5, pp. $23-26$.

${ }^{12}$ Sidney, Court Maxims, pp. 25-28. Ver Maquiavel, Discursos sobre a primeira década de Tito Lívio I, 58-59, pp. I66I75.
} 
seu julgamento como prova de seu envolvimento no complô $\hat{~}^{13}$. Embora não tenham uma forma acabada - Sidney foi executado em 7 de dezembro de I683 - os manuscritos publicados por John Toland em I698, com o título Discourses concerning government, apesar das inúmeras imprecisões, mostram o uso abundante do republicanismo de Maquiavel ${ }^{14}$.

A intenção desses manuscritos era a mesma de Two Treatiseson Government (i689) de John Locke e Patriarcha non Monarcha (I68I) de James Tyrrel, ou seja, refutar o Patriarcha de Robert Filmer, escrito na primeira metade do século, provavelmente entre I635 e I642, e publicado pelos realistas, em I680, como uma espécie de manifesto em favor da monarquia absoluta e hereditária (Daly, I978, pp. 227-250; Wallace, I980, pp.I55-I65).

Diferentemente de Locke que recorreu principalmente a uma linguagem da lei natural e de Tyrrel que refutou o Patriarcha sobretudo com relatos extraídos da história, em particular da história da Inglaterra, Sidney procurou fazê-lo do modo mais abrangente possível, seguindo a estrutura do texto de seu adversário, contestando-o parágrafo por parágrafo, numa réplica minuciosa de todos os argumentos mobilizados.

Como em Court Maxims, não há muitas vezes referências explicitas a Maquiavel. $O$ Príncipe, por exemplo, não é mencionado quando é afirmado que um monarca fraco não deve manter um conselho composto de homens sábios, porque corre o risco de perder seu poder e ser substituído por um governo aristocrático ${ }^{15}$. Só na defesa de que um sábio conselho não é capaz de suprir os defeitos ou corrigir os vícios de um monarca corrupto e que um povo não pode esperar nada de bom de um conselho escolhido por um monarca fraco ou depravado, a máxima é retomada com a devida citação ${ }^{16}$. Mas, como nas demais referências ao longo da obra, as ideias de Maquiavel são adaptadas ao argumento em questão, visto que no capítulo citado é sustentado apenas que o príncipe deve evitar aduladores e escolher homens sábios como conselheiros, deliberando por si mesmo depois de ouvi-los ${ }^{17}$.

Em sua refutação a Filmer, Sidney recorre mais uma vez aos argumentos utilizados por Maquiavel em favor do regime republicano. Por exemplo, contra a ideia de que a monarquia é superior por depender da decisão de um só homem, ele sustenta que a sabedoria conjunta de um povo ultrapassa de longe a de um monarca. Isto não por uma

\footnotetext{
${ }^{13}$ A lei inglesa exigia no mínimo duas testemunhas como prova de traição. Como o promotor do caso tinha apenas uma - Lord Howard - partes do manuscrito foram utilizadas pela primeira vez num processo judicial como uma segunda testemunha, para provar a intenção subversora de seu autor. Salmon, I954, pp.698-705.

${ }^{\mathrm{I}}$ Depois de sua publicação, em I698, a obra conheceu oito edições no decorrer do século XVIII, sendo traduzida para o francês em I702, I755 e I780, e para o alemão em I707 e I793. O texto de referência para as citações será a primeira edição, republicada e revisada por Thomas G. West em 1996.

${ }^{15}$ Sidney, Discourses concerning government I, 3, p. I4

${ }^{16}$ Sidney, Discourses concerning government III, I6, pp. 404-405.

${ }^{17}$ Maquiavel, O Príncipe, XXIII, pp.II3-II5.
} 
espécie de virtude oculta na multidão, mas pela presença conjunta da razão, que permite aos cidadãos tomar as melhores decisões para as questões que lhes dizem respeito ${ }^{\mathrm{I} 8}$.

Segundo Sidney, a superioridade das repúblicas está no fato de que os seus cidadãos têm um maior envolvimento com a coisa pública. Isto porque, como cada cidadão vê seu próprio bem incluído no bem público, esforça-se em preservá-lo, pois sabe que o prejuízo do bem público significa também o seu infortúnio. Isto encoraja a dedicação e o empenho em benefício da coisa pública, tornando as repúblicas mais prósperas do que as monarquias. Ao ver as honras adquiridas pelos magistrados, escolhidos entre os melhores cidadãos em frequentes eleições, todos procuram também adquirir a virtude necessária para ocupar os cargos públicos, pois sabem que seu sucesso só depende de seu mérito. Assim, as repúblicas favorecem o surgimento e o aperfeiçoamento das virtudes cívicas, que asseguram a liberdade e a prosperidade ${ }^{19}$.

No que se refere ao sucesso militar, Sidney argumenta que, se as conquistas dependem das qualidades de quem comanda e da coragem, número e valor dos soldados, as repúblicas superam de longe as monarquias. Isto porque, enquanto nas monarquias o comandante em chefe é o rei, que nem sempre tem experiência militar ou habilidade para comandar, nas repúblicas o comandante é selecionado entre os melhores cidadãos; e se este morre em combate, ao contrário do que acontece com a morte do rei, outros cidadãos com a mesma qualidade o substituem rapidamente ${ }^{20}$.

Parafraseando Maquiavel, Sidney sustenta que os melhores soldados são aqueles que lutam por eles mesmos e por sua posteridade e não soldados profissionais ou mercenários. Ao contrário das monarquias, em que os súditos tomam armas para servir a um senhor, cujo sucesso só lhes traz em geral prejuízos, as repúblicas têm cidadãos armados, que combatem em defesa do interesse público no qual está compreendido os seus próprios interesses. Além disso, não havia relatos históricos de repúblicas que tivessem sido conquistados por monarquias; e isto não podia ser atribuído somente à fortuna, mas à virtude de seus cidadãos. Na verdade, a história relatava inúmeros exemplos de vitórias militares de repúblicas sobre as monarquias, mesmo de pequenas repúblicas sobre grandes

\footnotetext{
${ }^{18}$ Sidney, Discourses concerning government III, I6, p. 403; III, I4, p. 397. Ver Maquiavel, Discursos sobre a primeira década de Tito Lívio I, 58, pp. I66-I72

${ }^{19}$ Sidney, Discourses concerning government II, I9, pp. I84-19I. Ver Maquiavel, Discursos sobre a primeira década de Tito Lívio II, 2, p. I87 e I9I

${ }^{20}$ Sidney, Discourses concerning government II, 23, pp. 2I2-2I6. Ver Maquiavel, Discursos sobre a primeira década de Tito Livio I, 20, p.79.
} 
reinos, em razão de seu maior vigor e força, adquiridos pela disciplina e boa ordenação de seus exércitos ${ }^{21}$.

Aproximando-se de Nedham e distanciando-se dos demais republicanos ingleses que preferiam os modelos de Esparta ou Veneza, Sidney adota Roma, em particular aquela descrita por Tito Lívio e por Tácito, como modelo de república a ser imitado pela Inglaterra. As razões desta escolha parecem ser extraídas principalmente dos Discursos sobre a primeira década de Tito Lívio.

Maquiavel contrariou toda uma tradição republicana que preferia o caráter pacífico e a concórdia de Esparta ou Veneza ao expansionismo ávido e às constantes dissensões internas de Roma. Para ele, a serenidade de Veneza era decorrente da sua posição geográfica isolada e de sua população homogênea; e a coesão de Esparta havia sido alcançada pela imposição da igualdade entre seus cidadãos e pela proibição da entrada de estrangeiros. Ambas experimentaram a estabilidade, mas porque se mantiveram fechadas, adotando uma política de conservação, isto é, de controle de sua população e de manutenção de seus territórios. Roma, ao contrário, desde suas origens, abriu as portas aos estrangeiros e o exército, ao povo. A fim de conservar a liberdade conquistada, depois da expulsão dos reis Tarquínios, instaurou uma política de expansão, ampliando sua população e seus domínios. A sua estabilidade foi alcançada graças ao dinamismo de suas instituições que se renovaram continuamente diante das circunstâncias históricas. Desse modo, enquanto o equilíbrio de Esparta e de Veneza podia ser caracterizado como estático, o de Roma havia sido dinâmico ${ }^{22}$.

Se a política de fechamento, adotada por Esparta e Veneza, parece ser mais segura, pois traz a estabilidade desejada, ela não é considerada a mais adequada no longo prazo, segundo Maquiavel, porque não se sustenta com a inevitável inconstância das coisas humanas. Por isso, ele propõe para as repúblicas modernas a política adotada por Roma, que acolheu a natureza mutável dos acontecimentos humanos, ao enfrentar os contínuos desafios da contingência ${ }^{23}$.

Nedham e Harrington já haviam utilizado esta distinção maquiaveliana entre repúblicas projetadas para a expansão, como Roma, ou para a preservação, como Esparta e Veneza $^{24}$. Mas não haviam tratado dos fundamentos e das consequências desta distinção, que é feita na discussão sobre a quem deve ser dada numa república a guarda da liberdade:

\footnotetext{
${ }^{2 I}$ Sidney, Discourses concerning government II, 23, pp. 2I2-2I6. Ver Maquiavel, O Príncipe, XII-XIII, pp.57-67; Discursos sobre a primeira década de Tito Lívio I, 2I. pp.79-8I; I, 43, p. I32; II, 20, pp.255-258

${ }^{22}$ Maquiavel, Discursos sobre a primeira década de Tito Lívio I, 6, pp. 27-30.

${ }^{23}$ Maquiavel, Discursos sobre a primeira década de Tito Lívio, I, 6, pp. 27-32.

${ }^{24}$ Nedham, The Excellencie of a Free State I, pp.27-3I; Harrington, The Commonwealth of Oceana, pp. 32-33.
} 
ao povo ou aos grandes. Maquiavel considera inicialmente as duas possibilidades. A guarda da liberdade tanto pode ser dada ao povo, como fez Roma, ou aos grandes, como fez Esparta e Veneza. A escolha parece depender do resultado desejado. Se o objetivo for a expansão e a potência, a liberdade deve ser confiada ao povo, como mostra o exemplo de Roma. Já se o objetivo for a tranquilidade e a longevidade, a liberdade deve ser confiada aos grandes, pois os exemplos de Esparta e de Veneza mostram que a serenidade depende da estabilidade dos grandes, que se acomodam melhor quando não se sentem ameaçados pelo povo e têm saciada sua ambição de poder ${ }^{25}$.

No final do capítulo, Maquiavel acaba sugerindo que a liberdade seja confiada ao povo, com o argumento de que o povo tem um desejo menor de violá-la. O desejo do povo é considerado mais próximo da liberdade, pois consiste simplesmente em não querer ser dominado, ao contrário dos grandes que jamais têm o desejo de apenas conservar o que possuem e buscam sempre novas conquistas. Por isso, é razoável esperar que o povo cumpra com o encargo de zelar pela liberdade com menos avareza e que, não desejando apropriar-se do poder para dominar, não permita que outros o façam. Como deseja apenas viver de maneira livre, o povo é capaz de salvaguardar melhor a liberdade, pois o seu interesse não se opõe à existência de um regime livre. Por tudo isso, conclui Maquiavel, o povo deve ser o guardião da liberdade ${ }^{26}$.

Sidney também prefere o dinamismo e o expansionismo militar de Roma à estabilidade e pacifismo de Esparta e Veneza, mas não por este critério da guarda da liberdade, questão que nem chega a discutir. Ele avalia apenas que, num mundo de recursos limitados e intensa competição entre as nações, a estratégia mais segura é estar sempre pronto para a guerra, com a intenção de conquistar novos territórios, e não simplesmente de se defender. Dessa maneira, nenhuma nação pode estar segura sem o ardor e a disposição para a conquista ${ }^{27}$.

Com base no exemplo dos romanos, Sidney pretende também enfatizar, de um lado, a relação entre liberdade e virtude, no sentido de a liberdade permitir a virtude, que por sua vez fomenta e sustenta a liberdade, o que resulta em vigor e prosperidade para a república; e, do outro, a relação entre vício e escravidão, que gera fraqueza e miséria, cujo resultado é a tirania ${ }^{28}$. Para ele, a principal lição deixada por Maquiavel foi de que a liberdade não pode subsistir se o vício e a corrupção predominarem na vida política ${ }^{29}$ :

\footnotetext{
${ }^{25}$ Maquiavel, Discursos sobre a primeira década de Tito Lívio L. I, 5, pp.23-25.

${ }^{26}$ Maquiavel, Discursos sobre a primeira década de Tito Lívio I, 5, pp. 25-26.

${ }^{27}$ Sidney, Discourses concerning government II, 22, p. 204-205.

${ }^{28}$ Sidney, Discourses concerning government II, II, pp.I34-I44; II, I5, pp.I6I-I63.

${ }^{29}$ Sidney, Discourses concerning government II, 30, p. 302; III, 46, p. 575; II, 9, p. I84.
} 
"Discursando sobre esses assuntos, Maquiavel pensa que a virtude é tão essencialmente necessária para o estabelecimento e preservação da liberdade que é impossível para um povo corrompido estabelecer um bom governo ou uma tirania ser introduzida se o povo é virtuoso" (Discourses concerning government II, II, p. I35).

O problema da corrupção é tratado por Maquiavel desde as primeiras páginas dos Discursos sobre a primeira década de Tito Lívio. Ao comentar a teoria polibiana da anaciclose, sustenta que a corrupção dos regimes políticos se dá em consequência da distância temporal e do enfraquecimento da necessidade que exigiu sua instituição: as gerações se sucedem, a urgência é esquecida e a corrupção se instaura. Assim, um regime político só se mantém saudável enquanto permanecer marcado pela urgência que o fez surgir; e conhece sua decadência quando essa necessidade se atenua ${ }^{30}$.

A corrupção é então avaliada em seus diferentes graus. No caso da república, se tiver se alastrado por todas as partes, atingindo o povo, a liberdade não terá mais lugar, a menos que surja um acontecimento extraordinário. $\mathrm{O}$ principal exemplo vinha de Roma, que conquistou e conservou sua liberdade, após a expulsão dos reis Tarquínios, porque o povo não estava totalmente corrompido. Contudo, não conseguiu recuperá-la, após a extinção dos Césares, porque aí o povo já se encontrava contaminado pela mais profunda corrupção ${ }^{3 \mathrm{I}}$.

Nos casos em que se chegou a um estágio máximo de corrupção, torna-se indispensável para Maquiavel o recurso a métodos extraordinários, a fim de promover uma reforma ampla e radical. Como as leis e as ordenações perderam sua eficácia, só um reformador, que tome e concentre todo o poder em suas mãos, é capaz de tomar as medidas necessárias para salvar a república. É preciso nesses casos retornar ao momento préjurídico da fundação, no qual o agente político encontra-se fora de toda legalidade e moralidade $^{32}$. Mas é feita a advertência de que será muito difícil encontrar um cidadão virtuoso que se disponha a usurpar do poder por meios ilegítimos, a fim de promover essa reforma radical; e se um cidadão ambicioso e corrupto o fizer, dificilmente vai fazer um bom uso do poder que conquistou com o $\mathrm{mal}^{33}$.

Nos casos em que a corrupção ainda não alcançou seu grau máximo, não atingindo todo povo, é possível combatê-la, segundo Maquiavel, com a renovação contínua, isto é, o retorno aos princípios que se encontram no momento da instituição da república, para que

\footnotetext{
${ }^{30}$ Maquiavel, Discursos sobre a primeira década de Tito Lívio I, 2, p. I2-I7.

${ }^{31}$ Maquiavel, Discursos sobre a primeira década de Tito Lívio. I, 2, pp. I8-I9.

${ }^{32}$ Maquiavel, Discursos sobre a primeira década de Tito Lívio I, 9, p. 4I-42.

${ }^{33}$ Maquiavel, Discursos sobre a primeira década de Tito Lívio I, I8, p. 72-76.
} 
seja recordada a necessidade de seu surgimento. Esse retorno não consiste numa simples reafirmação do conteúdo de sua constituição original, pois isso seria recusar a inevitável mudança das coisas humanas, mas na rememoração do momento no qual se deu a união dos homens e se alcançou o consenso para a formação da república. Os princípios para os quais é preciso retornar continuamente são de certa forma anteriores a todo conteúdo ${ }^{34}$.

Essa renovação contínua é pensada como resultado de três processos. O primeiro é totalmente extrínseco, quando a república fica exposta a um perigo externo, devido a um acaso qualquer, como uma invasão ou uma catástrofe natural. O segundo é intrínseco e depende do surgimento de homens virtuosos que se tornam modelos de conduta para os demais cidadãos, pelos seus atos de coragem e desprendimento, como ocorreu em Roma com Brutus, que se colocou no limite do direito para se opor a um poder corrompido. Mas ambos os processos dependem da contingência e são extremamente perigosos: o primeiro pode resultar no fim da república; o segundo pode gerar um estado de terror, pois esses grandes homens normalmente se colocam à margem da lei e recorrem à violência ${ }^{35}$.

Já o terceiro processo, que não é muito detalhado por Maquiavel, parece consistir na criação de mecanismos legais que produzam o contínuo retorno às origens de maneira regular, revigorando as instituições republicanas. Menos contingente e mais eficaz, parece ser tornar as leis mais efetivas e lhes dar novamente a sua força original, aplicando-as rigorosamente, e tornar as instituições mais atuantes ${ }^{36}$.

Parafraseando Maquiavel, sem citá-lo, Sidney também sustenta a necessidade da renovação contínua por meio do retorno aos primeiros princípios como forma de combater a corrupção ${ }^{37}$. Mas, enquanto Maquiavel defende um retorno à condição de necessidade que fez surgir a república e pensa que isto acontece pela virtude de um só homem ou pela virtude da própria constituiçãa ${ }^{38}$, Sidney parece identificar o povo como o agente natural da contínua renovação, uma vez que a sua vontade se encontra na origem de todo regime republicano ${ }^{39}$.

Sidney não concebe o problema da corrupção dos regimes políticos com base num movimento cíclico fixado por uma lei natural, como Políbio. Ele também não pensa que seja possível escapar da instabilidade inscrita na vida política pela adoção de uma determinada forma constitucional, uma vez que a estabilidade e a perfeição residem

\footnotetext{
${ }^{34}$ Maquiavel, Discursos sobre a primeira década de Tito Lívio III, I, pp. 305-3II.

${ }^{35}$ Maquiavel, Discursos sobre a primeira década de Tito Lívio III, 2-3, pp. 3II-3I5.

${ }^{36}$ Maquiavel, Discursos sobre a primeira década de Tito Lívio I, I6, pp. 64-68.

${ }^{37}$ Sidney, Discourses concerning government II, I3, p. I5O; II, 30, p. 302.

${ }^{38}$ Maquiavel, Discursos sobre a primeira década de Tito Lívio III, I, pp. 305-3II

${ }^{39}$ Sidney, Discourses concerning government III, 4I, p. 550-55I
} 
apenas em Deus ${ }^{40}$. Todas as instituições humanas, incluindo os governos, por estar inscritas na temporalidade, submetidas ao fluxo contínuo de todas as coisas, estão sujeitas à corrupção. Além disso, dificilmente uma constituição política é criada de maneira perfeita, pois os homens são incapazes de prever a infinita variedade de acidentes futuros, sendo benéficas as mudanças introduzidas para corrigi-la. As mudanças constitucionais não são assim um sinal de irregularidade, mas o testemunho do esforço humano em melhorar suas condições de existência política ${ }^{4 \mathrm{I}}$.

Também como Maquiavel, Sidney sustenta que os tumultos e conflitos civis, comuns nos regimes republicanos, podem ser saudáveis; e apesar de seus transtornos, são preferíveis à tirania. Repetindo o argumento utilizado em Court Maxims, defende que se os tumultos podem causar enfermidades para o corpo político, a tirania acarreta sua morte ${ }^{42}$.

Ao tratar dos conflitos civis, Maquiavel parte do pressuposto de que em todo corpo político encontram-se dois humores - termo emprestado da medicina hipocrático-galênica - dos quais nascem dois apetites divergentes: o desejo dos grandes de dominar; e o desejo do povo de não ser dominado. Se os dois desejos podem se afirmar conjuntamente, sendo até mesmo complementares, já que um não existe sem o outro, eles não podem ser saciados simultaneamente, porque a plena realização de um implica na impossibilidade de satisfação do outro: se o desejo dos grandes de dominar é totalmente realizado, o desejo do povo de não ser dominado não pode ser efetivado e vice-versa. O corpo político aparece desse modo como intrinsecamente cindido, marcado pela irredutível oposição de desejos assimétricos, que se chocam continuamente. Esse incontornável antagonismo de desejos opostos resulta num contínuo conflito entre as partes constituintes do corpo político, povo e grandes, em razão da impossibilidade de transpor a dessemelhança entre seus desejos ${ }^{43}$.

Enquanto a tradição republicana defendia que para desfrutar de uma vida livre era necessário instaurar a concórdia e a unidade entre as partes do corpo político, Maquiavel enfatiza que se deve aprender a preservá-la no interior dos conflitos, pois eles eram inerentes ao corpo político. Os conflitos, causados por desejos opostos das partes constituintes do corpo político, não podiam ser empecilho para a liberdade, que devia ser instaurada e mantida apesar dos desejos opostos.

Seguindo a concepção médica da época de que a saúde de todo corpo, humano ou político, depende do equilíbrio entre os seus humores, Maquiavel sustenta que nenhum

\footnotetext{
${ }^{40}$ Sidney, Discourses concerning government II,II, p. 136

${ }^{4 I}$ Sidney, Discourses concerning government II, I7, p. I73; II,I3, p. I5O; III, 22, p. 45I; III, 25, pp. 460-46I

${ }^{42}$ Sidney, Discourses concerning government III, 40, p. 545.

${ }^{43}$ Maquiavel, O Príncipe, IX; Discursos sobre a primeira década de Tito Lívio I, 4, pp. 2I-23.
} 
dos humores deve predominar, sendo necessário uma mediação, para o estabelecimento de um equilíbrio entre os diferentes humores. No caso das repúblicas, esta mediação deve ser feita pelas suas leis e ordenações, de tal modo que os homens não precisem recorrer à violência para satisfazer seus desejos.

Assim, se os conflitos são inevitáveis e instransponíveis, torna-se imprescindível, na perspectiva de Maquiavel, criar mecanismos institucionais que levem em conta a impossibilidade de resolver definitivamente a dessemelhança dos desejos e que sejam capazes de expressá-los mutuamente, para que eles não sejam coibidos ou sufocados. Sem tais mecanismos, os humores reprimidos geram facções e partidarismos que colocam em risco a existência da república. Por isso, é necessário oferecer meios e espaços públicos nos quais os conflitos possam ocorrer, sem que seja preciso recorrer à força ou a recursos privados. Só dessa maneira os conflitos, que poderiam ser desagregadores, podem ser mobilizados em benefício da república.

Ao tratar das primeiras dissensões em Roma entre patrícios e plebeus, Maquiavel ressalta os seus resultados: boas leis e a manutenção da liberdade. Mas reconhece que as dissensões também podem provocar violência e medo, impossibilitando um governo livre. Ele distingue então as disputas ocorridas no início do regime republicano em Roma, quando o desejo da plebe era participar do governo, sem dele excluir os patrícios, dos combates que marcavam a história de Florença, onde o desejo das partes envolvidas sempre foi exercer o poder de maneira exclusiva, excluindo a outra parte por meio do exílio e do sangue. Não há assim um elogio incondicional das dissensões. Se elas tiveram efeitos positivos em Roma, motivadas pela participação nos assuntos públicos, manifestadas na esfera pública e mediadas por mecanismos institucionais, elas tiveram efeitos nefastos em Florença, porque foram motivadas por interesses particulares e mobilizaram recursos privados ${ }^{44}$.

Maquiavel ainda adverte que o resultado das dissensões pode ser distinto não apenas em diferentes cidades, mas na mesma cidade em diferentes momentos. Em Roma, as primeiras dissensões entre patrícios e plebeus geraram boas leis e garantiram a manutenção da liberdade. Isto porque, ao representar um risco iminente para a sua existência, elas impuseram um estado de necessidade, que levou os romanos a agir para o bem, suprimindo todo recurso à escolha e às indecisões ${ }^{45}$. Porém, as disputas que se seguiram à promulgação da lei agrária pelos irmãos Graco alimentaram o ódio e causaram

\footnotetext{
${ }^{44}$ Maquiavel, Discursos sobre a primeira década de Tito Lívio I, 7-8, pp.33-40; História de Florença III, cap. I; VII, cap. I-2.

${ }^{45}$ Maquiavel. Discursos sobre a primeira década de Tito Lívio I, I, p. IO-II.
} 
a ruína da República ${ }^{46}$.

A questão então é entender como de um mesmo ponto de partida, as dissensões entre patrícios e plebeus, chegou-se a resultados tão opostos: num primeiro momento, a liberdade e a grandeza; num segundo, a guerra civil e a destruição da República. Primeiro, é apontado o trabalho do tempo sobre a lei agrária, de modo que, o que era inicialmente necessário para refrear o desejo dos patrícios de dominar, tornou-se posteriormente um instrumento de ambição dos plebeus; depois, é destacada a corrupção do próprio povo, de tal forma que o desejo dos plebeus se equiparou ao desejo dos patrícios em dominar. Ao abandonar seu desejo original de não ser dominado e ambicionar o domínio, os plebeus passaram a disputar com os patrícios os ofícios e as riquezas, gerando facções e conduzindo a República ao confronto armado ${ }^{47}$.

O pensamento republicano de Maquiavel foi mitigado por Nedham e Harrignton principalmente pela rejeição do pressuposto da inevitabilidade dos conflitos civis e da possibilidade de seus resultados positivos. Para Harrington, os conflitos são sempre prejudiciais para a república, não despertam ou alimentam a virtude cívica, e têm sua origem em defeitos dos arranjos institucionais. Eles podem e devem ser evitados por meio de ordenações que promovam a concórdia entre as partes que a compõem. Nesse sentido, o legislador deve buscar a unidade e a harmonia social por meio de uma constituição que estabeleça o equilíbrio entre os diversos interesses presentes na república. Apesar de sua admiração pela disciplina militar e pelas conquistas de Roma, esta República é tratada muito mais como ilustração de uma patologia política do que como um exemplo a ser seguido, uma vez que os seus contínuos tumultos prejudicaram sua estabilidade e perenidade. É muito mais a longevidade de Esparta e a serenidade de Veneza que inspira sua proposta de constituição para a Inglaterra do que o vigor e potência de Roma ${ }^{48}$.

No caso de Nedham, ao responder à objeção comumente feita ao regime republicano por suas frequentes dissensões, divisões e tumultos, ele argumenta que o povo tem um temperamento naturalmente pacífico, desejando apenas desfrutar de seus direitos em segurança; e mesmo se tivesse um temperamento belicoso, esses tumultos são menos inconvenientes do que a tirania dos monarcas. Além disso, eles ocorrem normalmente em três circunstâncias específicas - quando um cidadão ou um grupo de cidadãos arroga algum tipo de poder ou privilégio sobre os demais; quando o povo vê seus líderes transformarem-se em tiranos, ao abusar do poder que lhes foi confiado; ou quando o povo

\footnotetext{
${ }^{46}$ Maquiavel, Discursos sobre a primeira década de Tito Lívio I, 37, p. II2

${ }^{47}$ Maquiavel, Discursos sobre a primeira década de Tito Lívio I, 37, pp. II2-II6.

${ }^{48}$ Harrington, The Commonwealth of Oceana, pp. 36-38.
} 
sofre algum tipo de opressão por parte dos poderosos - e têm três características marcantes: não duram muito e são rapidamente extintos; as injúrias atingem apenas algumas pessoas; e os seus resultados, embora prejudiquem alguns particulares, contribuem normalmente para o proveito público, com a produção de boas leis ${ }^{49}$.

Já ao dar conselhos ao povo, para que mantenha sua liberdade, Nedham destaca a necessidade de fazer uso desta liberdade com moderação, a fim de que ela não se transforme em licenciosidade. Sugere então algumas precauções, para que isto não aconteça: escolher bem os magistrados, para que os eleitos sejam os mais eminentes e os mais apaixonados pela liberdade; avaliar apenas o mérito dos candidatos e não as possíveis alianças ou afeições pessoais; evitar falsas acusações e calúnias contra as autoridades públicas; não confiar o exercício do poder a alguém que depois não possa ser afastado de seu ofício; entre outras cautelas. Porém, a precaução mais enfatizada é evitar as dissensões e os tumultos, que conduzem muitas vezes ao confronto armado ${ }^{50}$.

Desse modo, Nedham distancia-se da perspectiva maquiaveliana, ao não diferenciar as dissensões que podem produzir bons resultados daquelas que podem resultar na destruição da república. Ele não diferencia nem os motivos nem as formas das dissensões. Isso faz com que elas sejam às vezes admitidas, pelos resultados positivos que podem gerar em favor da liberdade; às vezes criticadas, por causar o confronto armado. Mas na maior parte das vezes, como em Harrington, elas são consideradas perniciosas, por originar facções e colocar em risco a concórdia e a unidade da república ${ }^{5 \mathrm{I}}$.

Já Sidney admite o pressuposto de que os conflitos civis são inevitáveis em todo corpo político. Em sua avaliação, eles ocorrem por erro ou por malícia: procedem do erro, quando um povo toma o mal pelo bem, o que ocorre mais nas repúblicas do que nas monarquias, porque o povo toma mais decisões e por isso está mais sujeito ao equívoco; já as desordens civis provenientes da malícia são mais frequentes nas monarquias, provocadas pela constante malícia da corte, e raramente ocorrem nas repúblicas, porque o povo jamais deseja ferir-se a si próprio.

Sidney distingue ainda os motivos justos e injustos para os distúrbios civis. Para ele, sedições, tumultos e guerras civis ocorrem por motivos justos, sendo assim justificados pelas leis divinas e humanas, quando o magistrado, encarregado de executar e preservar a lei civil, acaba por subvertê-la. Eles ocorrem por motivos injustos quando visam a satisfação de interesses privados, sem considerar o bem público, o que raramente ocorre

\footnotetext{
${ }^{49}$ Nedham, The excellencie of a free State II, pp.64-68

${ }^{50}$ Nedham, The excellencie of a free State, IV, p. IO7-II5

${ }^{51}$ Nedham, The excellencie of a free State, IV, p. I I 0
} 
nas repúblicas, a não ser que o povo esteja totalmente corrompido; e é frequente em monarquias, onde o monarca não tem outra lei senão seus próprios caprichos.

Para Sidney, a superioridade das repúblicas está no fato de que elas estão menos sujeitas aos distúrbios sociais. Em sua avaliação, as monarquias sofrem mais distúrbios com suas frequentes disputas pela coroa, que normalmente dividem os súditos em facções, e com a posterior oposição dos vencidos. As monarquias estão ainda sujeitas a intensos conflitos quando mulheres, crianças ou loucos assumem o trono. Ao contrário, isto não ocorre nas repúblicas, onde a suprema magistratura é concedida aos mais virtuosos, eleitos pelo povo e por isso respeitados por todos ${ }^{52}$. Além disso, ao buscar melhores condições de vida aos seus cidadãos, as repúblicas despertam o amor pela pátria; e como cada cidadão se sente responsável pelo sucesso da coisa pública, pronto para defendê-la, os atritos tornamse inevitáveis. Assim, os tumultos nas repúblicas têm normalmente como causa sua política de expansão, que visa aumentar o número, a força, o poder e as riquezas do povo ${ }^{53}$.

$\mathrm{Na}$ interpretação de Sullivan, Sidney se move do republicanismo clássico, com suas premissas sobre a racionalidade do homem, a relevância das virtudes cívicas e das leis civis para a manutenção da liberdade, presentes na primeira e boa parte da segunda parte dos Discourses concerning government, para o republicanismo beligerante de Maquiavel, marcado pelo predomínio das paixões que exigem das repúblicas uma postura de guerra (Sullivan, 2006, pp. 58-86).

No mesmo sentido, Ward sustenta que a partir da metade da segunda parte de sua obra, influenciado pelas ideias de Maquiavel, Sidney distancia-se do republicanismo clássico. Prova dessa mudança é que ele expande seus argumentos contra a monarquia absoluta para todo tipo de monarquia, justificando as guerras de expansão territorial como um processo natural decorrente da hostilidade entre os povos; e passa a considerar as consequências saudáveis dos tumultos populares (Ward, 200I, pp.II9-I45).

De fato, a presença de Maquiavel vai se acentuando ao longo dos Discourses concerning government. Se a primeira parte é marcada pela clara influência do republicanismo clássico, em particular em sua matriz romana, o republicanismo de Maquiavel torna-se depois a principal referência na defesa da superioridade das repúblicas sobre as monarquias, mais especificamente das repúblicas que adotaram um governo popular, como Roma, mesmo com seus inevitáveis e intermináveis conflitos. Mas não há abandono de um em favor do outro. Há apenas uma combinação dessas duas matrizes do

\footnotetext{
${ }^{52}$ Sidney, Discourses concerning government II, 24, pp. 217-25I.

${ }^{53}$ Sidney, Discourses concerning government II, 26, pp. 259-263.
} 
pensamento republicano, cujo resultado é um republicanismo adaptado à tradição política inglesa.

Não é possível afirmar que Sidney tenha sido um fiel seguidor das ideias políticas de Maquiavel. Além de sua veemente crítica aos conselhos dados ao príncipe para conquistar e manter o poder, ele não endossa várias categorias maquiavelianas. Por exemplo, ao tratar da relevância das virtudes cívicas para assegurar a liberdade, permanece no quadro tradicional das virtudes cardeais e teologais, talvez sem compreender e, por isso, sem recorrer à noção maquiaveliana de virtù. Mas, se Nedham pode ser considerado o principal responsável pela propagação do republicanismo de Maquiavel na Inglaterra e Harrington o seu mais célebre divulgador, Sidney foi o autor inglês deste período que mais se aproximou de seus princípios, de seus enunciados e de suas consequências. Ainda se trata de uma interpretação parcial e seletiva do republicanismo de Maquiavel, mas menos problemática do que aquela de seus contemporâneos.

\section{Referências Bibliográficas}

BARROS, Alberto R. G. Republicanismo Inglês: uma teoria da liberdade. São Paulo: Discurso Editorial/FAPESP, 2015

BARROS, Alberto R. G. Maquiavel e o republicanismo inglês. Cadernos de Ética e Filosofia Política, n.24, 20I4, pp. 22-39.

CASWELL, John. The Porcupine. The Life of Algernon Sidney. London: Murray, 1989.

DALY, James. The Idea of Absolute Monarchy in Seventeenth-Century England. In: The Historical Journal, Vol. 2I, No. 2 (Jun., I978), pp. 227-250

HAYDON, Brigid. Algernon Sidney, I623-I683. Archaeologia Cantiana, vol.76, I96I, pp.IIo-I33. HARRINGTON, James. The Commonwealth of Oceana and A System of Politics. (ed. J. G. A. Pocock). Cambridge: Cambridge University Press, I992.

MAQUIAVEL. O Príncipe. São Paulo: Martins Fontes, 2004.

MAQUIAVEL. Discursos sobre a primeira década de Tito Lívio. São Paulo: Martins Fontes, 2007.

MAQUIAVEL. História de Florença. São Paulo: Martins Fontes, 2008.

NEDHAM, M. The Excellencie of a Free State. London, I656, disponível em www.constituion.org/cmt/nedham/nedham.htm. 
POCOCK, John. The machiavellian moment: florentine political thought and the atlantic republican tradition. Princeton: University Press, 1975

RAAB, Felix. The English Face of Machiavelli: a changing interpretation I50O-I70o. London: Routledge \& Kegan Paul, 1965

SIDNEY, Algernon. Court Maxims. Cambridge: Cambridge University Press, 1996.

SIDNEY, Algernon. Discourses concerning government. Indianapolis: Liberty F., 1996.

SULLIVAN, Vickie B. Muted and Manifest English Machiavellism: The Reconciliation of Machiavellian Republicanism with Liberalism in Sidney's Discourses Concerning Government and Trenchard's and Gordon's Cato Letters. In: RAHE, Paul A. Machiavelli's Liberal Republican Legacy. Cambridge: Cambridge University Press, 2006, pp. 58-86.

WALLACE, John. The date of Sir Robert Filmer's Patriarcha. In: The Historical Journal, n.23, I980, pp.I55-I65.

WARD, Lee. Rethoric and Natural Rights in Algernon Sidney's Discourses Concerning Government. In: Interpretation, vol.28, n.2, 200I, pp.II9-I45. 